\title{
Effect of reward system among health care workers performance: a case study of university of Calabar teaching hospital Calabar, Nigeria
}

\author{
Oyira Emilia James ${ }^{* 1}$, Regina Ella ${ }^{1}$, Nkamare SE ${ }^{2}$, Felicia E. Lukpata ${ }^{1}$, Sylvia Lazarus Uwa ${ }^{1}$, Partric Awok Mbum ${ }^{2}$ \\ ${ }^{1}$ Department of Nursing Sciences, Faculty of Allied Medical Sciences. University of Calabar, Calabar, Nigeria \\ ${ }^{2}$ Department of Marketing, Faculty of science. University of Calabar, Calabar, Nigeria
}

Received: December 14, 2014

DOI: $10.5430 /$ jha.v4n3p45
Accepted: February 9, $2015 \quad$ Online Published: April 13, 2015

URL: http://dx.doi.org/10.5430/jha.v4n3p45

\begin{abstract}
The study investigated the effect of reward system on health care workers performance in Teaching Hospital. It examined the relationship among monetary and non-monetary rewards and employees' performance in University of Calabar Teaching Hospital (UCTH). Desk survey was used in gathering relevant information. Primary sources were questionnaire, observation and interview, while secondary data were gathered from internet, textbooks, journals and libraries. Chi-square statistical tool was used and the findings revealed the monetary reward had a positive impact on employees' performance while non-monetary rewards had a negative effect on employees' performance. The study recommended that management of UCTH should boost the morale of their employees through fair and equitable reward system. The study further recommended that management should be effective with monetary rewards like bonuses and fringe benefits to encourage the workers improve performance.
\end{abstract}

Key Words: Reward system, Healthcare workers, Workers' performance, Monetary reward, Fringe benefits

\section{INTRODUCTION}

Every reward system is based on the assumption that rewarding employees would attract, retain and motivate workers. Thus any reward system that fails to achieve these would be considered as an ineffective reward system. ${ }^{[1]}$ Over the years, researchers in this field have held that financial reward is the best motivating and reinforcer of workers' morale. But recently management do not see the need to pay employees as when due. Institutional corruption, bias, and outright nepotism make managers to bend backward by misappropriating the money for frivolities and something else rather than paying the workers due. Workers need money to meet daily private demands and that's why they offer out their services in return of consideration. Any organization that do not have concern for workers welfare tend produce less and is vulnerable to failure. Money is needed to set up and maintain organizations. ${ }^{[2]}$ Securing land or set of equipment, recruitment of staff and maintenance of production all require money. In the same vein, Dewhurst ${ }^{[3]}$ ascertained that, there are other means to reward employees other than financial compensation. Some of these include: recognition, commendation, the praise that employees are able to get from their managers, the opportunity to take on important projects or tasks and also leadership attention. This would work out if the monetary reward is added to non-monetary rewards. These motivating factors seamlessly appeal to workers most when reward

\footnotetext{
*Correspondence: Oyira Emilia James; Email: emioyira@yahoo.com; Address: Department of Nursing Sciences, Faculty of Allied Medical Sciences. University of Calabar, Calabar, Nigeria.
} 
systems are put at the front burner and are therefore considered as excellent means to encourage the employee to work harder and yield high results for the organization. ${ }^{[4]}$ This is precisely because, the well-rewarded employee feels more committed to the organization and therefore works harder and better to achieve organizational goals and objectives.

\subsection{Statement of the problem}

In Nigerian, especially public organizations like the one under study, there appear to be a nonchalant attitude of managers towards workers' motivation. The reward system is often not very encouraging. The salaries and wages are low and sometimes not paid as at when due. This is the problems that agitate the hearts and minds of workers and these researchers which seem to be the root cause of the nonchalant attitude to work amongst Nigerian workers. This seems to be also the reason why Nigeria Gross Domestic Product (GDP) has been very low resulting to huge brain drain. ${ }^{[5]}$ This research therefore aims at making it clear in specific terms the effect of monetary reward system and employees performance.

The researchers are not aware of any study of this nature in respect of the said institution, while studies concerning other institutions with generalization include but not exhaustive by Ahmad S et al. ${ }^{[6]}$ and others.

\subsection{Research questions}

- What is the relationship between monetary reward and health care workers performance?

- What is the relationship between non-monetary reward and health care workers performance?

\subsection{Research hypothesis}

- $H_{01}$ : There is no significant effect between monetary reward and healthcare workers performance.

- $H_{02}$ : There is no significant effect between non- monetary reward and healthcare workers performance.

\section{THEORETICAL REVIEW OF RELATED LIT- ERATURE}

Levels of pay may be based on long-standing structures which were created in the mist of time and have not been updated since then in response to movements in market rates and inflation and negotiations have not been effected in most organizations. It is on this note, the researchers decides to investigate the effect of monetary and non-monetary rewards performance in the University of Calabar Teaching Hospital (UCTH).

\subsection{Monetary rewards}

Every organization especially UCTH needs a strategic reward system for employees. ${ }^{[7]}$ Rewards play an important role in organizations. ${ }^{[8]}$ Monetary rewards can also be referred to as tangible returns which include; cash compensation such as bonus, increment, short term incentives, long term incentives and other benefits such as income protection, allowances and others. ${ }^{[9]}$ Monetary reward can be profit sharing, job evaluation and merit rating. Profit sharing is organization profits that are given to all employees in that organization and is distributed based on their performance in the organization and this can be identified as reward outstanding performance. Job evaluation is where many factors had been identified and used as the purpose of inter-job comparison. The total rating for each job then forms the basis of wage structure. The factors that had been evaluated are working environment, physical and mental characteristics. Other examples of monetary reward are basic pay, merit or cost of living and bonus.

Basic pay is the payment that is received as a wage or as salary. ${ }^{[10,11]}$ Basic pay is the fixed payment paid to an employee for performing their specific job responsibilities ${ }^{[11,12]}$ argued that merit pay is a basic term for any mechanism that is used to adjust salaries or provide compensation to reward higher level of employee task in organization ${ }^{[13]}$ was used as a tool by an organization to motivate employee, hence it can increase their level of performance and minimize potential conflicts and challenges from employees. ${ }^{[14]}$ Merit pay is more likely to be considered as a reward programmes. ${ }^{[15]}$ Also, merit pay is the allocation of pay raises based on individual performance, and one of the most prevalent compensation practices used by most employers in private sector, state government and local governments. ${ }^{[16]}$

Performance bonus is a monetary reward that is given by employer to employees based on their performance appraisal and organization's profit. ${ }^{[17]}$ A bonus scheme is not an easy task to accomplish successfully in the organizations. ${ }^{[18]} \mathrm{A}$ successful bonus scheme depends on performance of organization and focus on efficiency of goal setting process. Monetary rewards that is preferred by employees especially in the lower level category, is money in a form of bonus, trips paid for by the organization, gifts from a rewards catalog, or services such as cell phone or paid cable. ${ }^{[4]}$ Thus, monetary rewards also refer to the financial inducement that organizations offer employees in exchange for their contribution and recognition in influencing their productivity in the organization.

\subsection{Non-monetary reward}

Non-monetary are also referred to as intangible returns or rational returns such as recognition, status, employment secu- 
rities and others. Non-monetary rewards refer to thank you, and praises from the manager. ${ }^{[19]}$ Hence, acknowledging employee contributions. Another example of non-monetary reward is the opportunity to learn and develop as an employee in the organization, flexible working hours, recognition from employers, the opportunity to contribute, independence and autonomy in their working areas.

Non-monetary reward also include valuing the worker on the part of the manager, allowing the worker to make mistakes during learning opportunity that gives an effect to the employee performance. The recognition of employee successes is a powerful tool in improving employee performance, morale, motivation, and employee productivity. ${ }^{[6]}$ Recognition is an important feeling that a person is made to feel special and this type of recognition must come from those employees, hold in high esteem and position, such as manager. ${ }^{[20]}$ Learning opportunities should be given to the employee. Learning opportunity is important to manage organizational activities, when well managed it can become a tool for improving employee performance. There are few ways to the employee learning such as give training, let them manage resources including facilities, build learning plans to encourage employees for career development and job growth.

Challenging work means an increase in the scope of work to the highest level of individual's capability so that employees become more energetic in handling and performing their job. ${ }^{[21]}$ Staff retention start with challenging work, ${ }^{[22]}$ he proposed five steps that will ensure that employee would feel challenged and grateful because his/her work through their performance. Firstly, screen carefully, so as to determine which is fit to be chosen to face a challenge in their work. Second, encourage creativity; employer must encourage the employee to use their creativity in handling their work, so that they can expand and improve them self in their performance. Third, delegate which employer must give opportunity to the employee to try out all of their skills by taking on higher level work responsibility. Fourth, formulate an active program of training that would lead to staff retention. Through training they can improve their skill well and become expert employee in their working areas. Lastly, let people make mistakes as they try to improve things; let employee have a freedom to make mistake and from this mistake they will learn something new and become better persons. This will improve their performance. ${ }^{[7]}$

Several studies have investigated possible ways to improve employee's performance such as:

\subsubsection{Reduce employee stress}

Several organizations also believe that reducing employee stress is the potential way to reduce dissatisfaction and in- creased their performance. Employer must identify a direct ways to decrease or reduce potential stressors. It can be done by reducing employee role conflict in employees' job descriptions and responsibilities. In another way, an employer can also reassign tasks or implement a job rotation program to reduce employee overload and burnout.

\subsubsection{Encourage flexible work schedules}

Additional stressors for employee are the balance between their work and their life responsibilities. By providing employees with a more flexible work hour, stress would be reduced, employee performance will be improved.

\subsubsection{Give meaningful and consistent praise}

Employers' recognition is very important towards employee performance. Recognition towards employee accomplishment will make employee happy that, they are an important asset to the organization and in its development.

\subsubsection{Maintain an honest communication}

Communication is important between employees and employers. Good communication will provide a good relationship between employee and employer.

\subsubsection{Provide wellness program}

A final strategy used to increase employee performance is implementing a wellness program that can increase employee productivity, improves physical and mental health, and reduce negative environment that can enhance stress. The wellness program or activity such as small gymnasium, a relaxation and meditation area, nutrition and medical consultation, or massage therapy sessions.

According to Penny speech at the World's Largest Human Resources Conference, there are seven ways an organization can motivate his employee such as:

(1) Treat employees with respect

(2) Recognize their work

(3) Give a clear picture of organizational goals

(4) Appreciate their ideas

(5) Give opportunity to them to solve problems in their own way

(6) Let the employee learn new things

Let the employee have pride in feeling that they are part of something important. When this is done appropriately, the effects would clearly be noticeable. These effects may include the following:

\subsection{Basic pay and employees' performance}

Where basic pay is given to employee based on the employees' skill levels and on the experience. ${ }^{[19]}$ This will improve the employee productivity. There are 13 factors that win 
influence pay rate and these factors can influence and give effect between employee/basic pay and employee productivity. ${ }^{[23]}$ Inadequate basic pay as a monetary reward also gives a great impact to the employee performance such as lateness, absenteeism, low performance, feeling of grievances and others which can bring a major problem to the organization. ${ }^{[24]}$

\subsection{Effect of performance bonus on employee perfor- mance}

Bonuses have strong relation with employees performance. Performance bonuses give an effective positive impact to individual or team performance. ${ }^{[25,26]}$ Recognition is to acknowledge the positive behavior and actions of your employees and boost morale among the ranks. There are three types of recognition such as:

(1) Honor wall: employer need to recognize an employee efforts and their work performance in public.

(2) Visit from Owner: employer needs to schedule a special surprise visit at her job area or while they are performing their regular duties. Employer need shake her hand and personally congratulate the employee on their work.

(3) Recognition Output: employer can schedule the outing activities during work for the employee that had been chosen or recognized. This will inspire other workers to strive for. Excellence so that they can receive the same benefit for the round.

Learning opportunities provide benefits to both employee and employers. Successful employee in learning development gives an effect to the employee job productivity and the employee's performance. ${ }^{[27]}$

\subsection{Effect of challenging work on employees' perfor- mance}

Challenging work give effect to the individual's capability so that employees become more energetic in handling and performing their job and this will improve their employee performance leadership and motivation training. ${ }^{[28]}$

\subsection{Effect of career advancement on employees' perfor- mance}

Career advancement encompasses everything in the process through which an employee progresses to achieve the highest position from the beginning of our career to the time until we retire. ${ }^{[29]}$ The examples of career advancement are job enrichment, promotion, job enlargement and others. In this study, she stated that job enrichment give a great impact and improvement to the job performance. ${ }^{[30]}$ However, promotion is the most important target for the employee career advancement as a way to improve their credibility and performance. There are seven ways to improve performance in order to get promotion there are ${ }^{[29]}$ work appreciation, make yourself indispensable, be aware of changes at work, update resume, volunteer at work, plan personal financial and live simply.

\section{METHOD}

\subsection{Research design}

In this study a mix-method approach was employed. This is to ascertain the effect of reward system on employee's performance. Primary and secondary sources were collected through questionnaires and materials. This method was used because it suits the phenomenon under investigation. This is in line with who stated that survey only described a set of data but does not make judgment. ${ }^{[31]}$

\subsection{Study area}

This study was conducted in the UCTH, Calabar. Calabar is the capital of Cross River State and is made up of two out of the eighteen local government areas. It is an old city in the history of Nigeria.

It has an area of about $535.9 \mathrm{~km}^{3}$ with an estimated population of about two hundred and seventy seven thousand (2006 census). Calabar is almost an Island with a heterogeneous landscape otherwise seen as undulating with slopes where land terminates in a river. It is peaceful with tourist attractions such as Tinapa. Calabar harbors UCTH. This hospital was established in 1978 to render tertiary health services to the people of Cross River State, its environs and the country at large. It is located in three areas, two sites along Moore Road and one site along Uncial Hotel Road. One site is situated in the former St. Margaret Hospital and is bounded by the school of midwifery, High Court, Health centre and Banks, West, North East and south respectively. It comprises of antenatal ward, upper block, labour ward, postnatal ward, gynecological ward, intensive care baby unit. Chief nursing officer head each of the ward. The permanent site is bounded by Unical Hotel, Satellite Town, and University of Calabar.

The functions of the UCTH as a tertiary facility include:

- Treatment of both minor and terminal conditions

- Rehabilitation services

- Receiving referral cases from secondary institutions

- Provision of preventive health services to clients

It is a 250 bedded hospital. The clinical section include nursing service, medicine and surgery, obstetrics and gynecology, pediatrics, orthopedic and physiotherapy while the supportive department include administrative, accounting, supplies and stores, laundry, security and works. 
The chief medical director heads UCTH. Designed offices in charge head each department. The hospital is well structured and equipped with modern facilities.

\subsection{Population of the study}

"Population comprises the totality of units having certain defined characteristics in common". ${ }^{[11]}$ This study was conducted using staff of UCTH. The population of the study covers all the permanent workers comprising of junior, senior and management staff. The population of the study comprises two hundred and seventy seven (277) workers in UCTH. This number constitutes the target population.

\subsection{Sample size determination}

The samples size was determined using Yaro-Yamane's statistical formula and it was obtained as follows:

$$
n=\frac{N}{1+N(e)^{2}}
$$

Where $\mathrm{n}$ is sample size; $\mathrm{N}$ is Total population; 1 is a unit known as constant and "e" is the level of significance ( .05) with the above formula.

Therefore

$$
\begin{aligned}
n & =\frac{277}{1+277(e)^{2}}=\frac{277}{1+277(0.05)^{2}}=\frac{277}{1+277 \times 0.0025} \\
& =\frac{277}{1.69}=163
\end{aligned}
$$

\subsection{Procedure for data collection}

Primary source: The primary source used in collection of the necessary data was questionnaire, which was designed to enhance the exhaustive retrieval of relevant data. The primary data was also extracted from personal interview and observation.

Secondary source: Was obtained from textbooks, journals, newspapers, magazine and published journal on internet as well as other relevant materials was useful in this study. This type of data has to do with documents that are in existence. Therefore, the data collection method was purely hand delivery. The staffs were at various departments. The researchers introduced themselves and briefed them on their mission. The questionnaires were distributed to respondents at random by the researchers.

\subsection{Ethical consideration}

To carry out this study, letter of introduction was collected from the Department of Nursing Science which introduced the researchers to the area of the study for further introduction to the chairman ethical committee; the approved letter was given to the Assistant director of nursing services (ADNS). The respondents (health workers) were assured of confidentiality and anonymity in order to ensure honest answers.

\subsection{Research instrument}

Based on the nature of this research work, the researchers employed structured questionnaire and pre-tested for comprehension. The questionnaire consisted of two sections $\mathrm{A}$ and B. Items in this section was designed on 5 point Likert scale with SA for Strongly Agree, A for Agree, U for undecided, D for Disagree and SD for Strongly Disagree.

The formulated questions were based on the objectives of the study; 1) what is the effect of monetary reward on healthcare workers performance, and 2) what is the effect of nonmonetary reward on healthcare worker performance.

\subsection{Technique of data analysis}

Chi-square statistical tool was adopted to establish the effect of independent on dependent variable.

$$
\chi^{2}=\frac{\left(F_{o}-F_{e}\right)^{2}}{E}
$$

Where: $\chi^{2}$ is Chi-square hypothesis distribution; $F_{0}$ is the observed data or frequencies; $F_{e}$ is the expected data or frequencies.

This tool is often considered as a measure of discrepancies $F_{0}$ and the expected frequencies $F_{e}$. If there is no discrepancy, the $\chi^{2}=0$. As the discrepancy becomes longer, the value of $\chi^{2}$ are evaluated by the two distribution. The chisquare $\chi^{2}$ distribution as a statistical tool is also referred to as Goodness of fit.

\section{Results}

\subsection{Distribution of respondents}

One hundred and sixty three (163) copies of questionnaires were given out. Majority of the respondents representing 52.20 percent are male while 44.80 percent of the total respondents are female. 50 respondents representing 30.6 percent, the ages of 30-39 years representing 24.5 percent and respondents representing 20.4 percent. Majority of the respondents representing 49.2 were single, 40 respondents representing 24.5, 33 respondents representing 20.2 percent, 10 respondents representing 6.1 percent (see Table 1).

Of 49.2 percent of respondents were FSLC/SSCE holders, 20.2 percent of respondents were OND holders, 12.2 percent of respondents were HND/B.Sc and 18.4 percent of the 
respondents were Masters/Ph.D holders. 20 of the respondents representing 12.2 percent had less than 2 years work experience, while 23 respondents representing 14.1 percent were 3-8 years, 20 respondents representing 12.2 percent were 9-14 years, 50 respondents representing 30.6 percent were 15-20 years and 50 respondents representing 30.6 percents were 15-20 years and 50 respondents representing 30.6 percent were above 20 years (see Table 1 ).

Table 1. Distribution of respondents

\begin{tabular}{|c|c|c|c|}
\hline & Category & No of respondents & $\begin{array}{l}\text { Relative } \\
\text { percentage }\end{array}$ \\
\hline \multirow{3}{*}{ Sex } & $\mathrm{M}$ & 90 & 55.20 \\
\hline & $\mathrm{F}$ & 73 & 44.80 \\
\hline & Overall & 163 & 100 \\
\hline \multirow{5}{*}{ Age category } & A & 50 & 30.60 \\
\hline & B & 40 & 24.50 \\
\hline & $\mathrm{C}$ & 40 & 24.50 \\
\hline & $\mathrm{D}$ & 33 & 20.40 \\
\hline & Total & 163 & 100 \\
\hline \multirow{5}{*}{ Marital status } & Single & 80 & 49.20 \\
\hline & M & 40 & 24.50 \\
\hline & Divorced & 33 & 20.20 \\
\hline & Widow/widower & 10 & 6.10 \\
\hline & Total & 163 & 100 \\
\hline \multirow{5}{*}{$\begin{array}{l}\text { Educational } \\
\text { qualification }\end{array}$} & FSLC/SSCE & 80 & 49.20 \\
\hline & OND & 33 & 20.20 \\
\hline & HND/B.SC & 20 & 12.20 \\
\hline & Masters/Ph.D & 30 & 18.40 \\
\hline & Total & 163 & 100 \\
\hline \multirow{6}{*}{$\begin{array}{l}\text { Work } \\
\text { experience }\end{array}$} & Less than SA & 20 & 12.20 \\
\hline & A & 23 & 14.10 \\
\hline & UD & 20 & 12.20 \\
\hline & $\mathrm{D}$ & 50 & 30.60 \\
\hline & SD & 50 & 30.60 \\
\hline & Total & 163 & 100 \\
\hline
\end{tabular}

Note. Source: Fieldwork, 2013

\subsection{Data analysis and interpretation}

Twenty respondents representing 12.2 percent, Strongly Agree on monetary rewards influence on employee's performance among staff of UCTH, 30 respondents representing 18.40 percent Agree to monetary rewards influence on employee's performance among staff of UUTH 50 respondents representing 30.7 percent were Undecided, 50 respondents representing 30.7 percent Decided on monetary rewards influence on employee's performance among staff of UCTH and 13 respondents representing 7.89 percent Strongly Disagree on monetary rewards influence on employee's performance among staff of UCTH (see Table 2).

Twenty respondents representing 12.2 percent, Strongly Agree on monetary rewards to effective performance, 23 respondents representing 14.1 percent Agree to monetary rewards to effective performance, 20 respondents representing 12.2 percent were Undecided, 50 respondents representing 30.6 percent Decided and 50 respondents representing 30.6 percent Strongly Disagree on monetary rewards to effective performance. Also, 60 respondent representing 36.8\% Strongly Agree, 20 respondents representing 3.83 percent Agree, 60 respondents representing 36.8 percent were undecided, 20 respondents representing 12.2 percent were Decided and 3 respondents representing 1.8 percent Strongly Disagree on proper monetary rewards enhance organization effectiveness (see Table 2).

Majority of the respondents representing 73.6 percent Strongly Agree to monetary rewards contributed to labour turnover, 10 respondents representing 6.1 percent Agree, 33 respondents representing 20.2 percent were Undecided and no respondents decided and Strongly Disagree to monetary rewards contributed to labour turnover. Majority of the respondents representing 49.1 percent were Strongly Agree, 20 respondents representing 3.83 percent Agreed, 20 respondents representing 3.83 percent were undecided and 23 respondents representing 14.1 percent were decided and no respond on Strongly Disagree to monetary rewards like bonuses and fringe benefits stimulate workers to put in their best (see Table 2).

Of $36.8 \%$ were in the category of Strongly Agree, 20 respondents were in the category of Agree, 20 respondents were in the category of Undecided and decided, lastly 43 respondents representing 43 Strongly Disagree that monetary rewards has an impact on job satisfaction. Majority of the respondents representing 6.13 percent were in the category of Strongly Agree, 43 respondents representing 26.3 percent were in category of Agree, 20 respondents representing 3.83 percent were in the category of Undecided while no respond was given to category of Decided and Strongly Disagree on when employees work in teams, it fosters work relationship and monetary benefits (see Table 2).

The majority of respondents representing 79.8 percent Strongly Agree to if non-monetary rewards influence employees' performance, 23 respondents representing 14.1 percent agreed with the statement, while the remaining respondents were undecided, decided and Strongly Disagree to the statement. Majority of the respondents representing 92 percent Strongly Agree that non-monetary rewards reduce labour turnover, 13 respondents representing 8.0 percent Agreed, while no response on Undecided, Decided and Strongly Agree to non-monetary rewards reduce labour turnover (see Table 2).

Of 160 respondents representing 98 percent Strongly Agree on non-monetary rewards leads to non-productivity, 3 respondents representing 2 percent were in the category of Agree. The respondents were not responded to other categories (see Table 2). 
The majority of the respondents representing 100 percent egories were nil. The $\chi^{2}$ statistical tool which is used to Strongly Disagreed on the statement that non-monetary re- test the reliability of the research conducted to know if it is ward promotes organizational performance, while other cat- acceptable or rejected (see Table 2).

Table 2. Data analysis and interpretation

\begin{tabular}{|c|c|c|c|c|c|c|}
\hline & Responses & SA & $\mathbf{A}$ & UD & D & SD \\
\hline \multirow{2}{*}{$\begin{array}{l}\text { Employee's performance among staff } \\
\text { of UCTH }\end{array}$} & No. of respondents & 20 & 30 & 50 & 50 & 13 \\
\hline & Relative percentage & 12.20 & 18.40 & 30.70 & 30.70 & 8.00 \\
\hline \multirow{2}{*}{ Effective performance } & No. of respondents & 20 & 23 & 20 & 50 & 50 \\
\hline & Relative percentage & 12.20 & 14.10 & 12.20 & 30.60 & 30.60 \\
\hline \multirow{2}{*}{ Organization effectiveness } & No. of respondents & 60 & 20 & 60 & 20 & 3 \\
\hline & Relative percentage & 36.80 & 12.20 & 36.8 & 12.20 & 2.00 \\
\hline \multirow{2}{*}{ Contribute to labour turnover } & No. of respondents & 120 & 10 & 33 & - & - \\
\hline & Relative percentage & 73.60 & 6.10 & 20.20 & - & - \\
\hline \multirow{2}{*}{$\begin{array}{l}\text { To stimulate workers to put in their } \\
\text { best }\end{array}$} & No. of respondents & 80 & 20 & 20 & 23 & 20 \\
\hline & Relative percentage & 49.08 & 12.27 & 12.27 & 14.11 & 12.27 \\
\hline \multirow{2}{*}{ Job satisfaction } & No. of respondents & 60 & 20 & 20 & 20 & 43 \\
\hline & Relative percentage & 36.81 & 12.27 & 12.27 & 12.27 & 26.38 \\
\hline \multirow{2}{*}{$\begin{array}{l}\text { Work relationship and monetary } \\
\text { benefits }\end{array}$} & No. of respondents & 100 & 43 & 20 & - & - \\
\hline & Relative percentage & 61.33 & 26.40 & 12.27 & - & - \\
\hline \multirow{2}{*}{ Employees' performance } & No. of respondents & 130 & 23 & 5 & 2 & 3 \\
\hline & Relative percentage & 79.75 & 14.11 & 3.07 & 1.23 & 1.84 \\
\hline \multirow{2}{*}{ Reduce labour turnover } & No. of respondents & 150 & 13 & - & - & - \\
\hline & Relative percentage & 92.02 & 7.98 & - & - & - \\
\hline \multirow{2}{*}{ Leads to non-productivity } & No. of respondents & 160 & 3 & - & - & - \\
\hline & Relative percentage & 98.16 & 1.84 & - & - & - \\
\hline \multirow{2}{*}{ Promotes organizational performance } & No. of respondents & - & - & - & 163 & - \\
\hline & Relative percentage & - & - & - & 100 & - \\
\hline
\end{tabular}

Note. Source: Fieldwork, 2013

\subsection{Decision rule}

Critical value of .05 at $4 \mathrm{df}=9.49$ from the $\chi^{2}$ analysis of the $H_{0}$, the calculated value is 37.30 while critical value is 9.49 (see Table 3).

Table 3. Monetary rewards relationship and performance of $\mathrm{UCTH}$

\begin{tabular}{llllll}
\hline Items & $\mathbf{O}$ & $\mathbf{E}$ & $\mathbf{F}_{\mathbf{0}}-\mathbf{F}_{\mathbf{e}}$ & $\left.\mathbf{( F}_{\mathbf{0}}-\mathbf{F}_{\mathbf{e}}\right)^{2}$ & $\left(\mathbf{F}_{\mathbf{0}}-\mathbf{F}_{\mathbf{e}}\right)^{2} \mathbf{F e}$ \\
\hline Strongly & 20 & 32.6 & -12.6 & 158.76 & 4.87 \\
Agree & & & & & \\
Agree & 30 & 32.6 & -2.6 & 6.76 & 2.07 \\
Undecided & 50 & 32.6 & 17.4 & 302.76 & 9.29 \\
Decided & 50 & 32.6 & 17.4 & 302.76 & 9.29 \\
Strongly & 13 & 32.6 & -19.6 & 384.16 & 11.8 \\
Disagree & & 163 & 0 & 1155.2 & 37.30 \\
Total & 163 & 163 &
\end{tabular}

The $\chi^{2}$ rules states that where the calculated value is greater reject the $H_{0}$ where critical greatest accept $H_{0}$. The $H_{1}$ hypothesis is upheld where $H_{0}$ is rejected. It is concluded that monetary rewards has positive impact on employee's performance in UCTH (see Table 4).

Critical value of .05 at $4 \mathrm{df}=9.49$ From the $\chi^{2}$ analysis $H_{0}$, the calculated value is greater than the critical $372.8=9.49$. Applying the $\chi^{2}$ rule, $H_{0}$ is rejected and $H_{i}$ is upheld. Therefore non-monetary rewards has positive impact on employees performance in UCTH.

\subsection{Discussion of findings}

The study empirically examined effect of reward system among health care workers performance. In hypothesis I, it is revealed that, monetary rewards has positive effect on employees performance. Dr. Nelson opined that monetary rewards are tangible returns which include bonus, increment, benefits and allowance that contributed to the positive impact of employee's performance. ${ }^{[19]}$ The study is in conformity with the works of ${ }^{[20]}$ who opined that monetary rewards are profit sharing, job evaluation and merit rating that are given to all employees in that organization and is distributed based on their performance. 
Table 4. Non-monetary rewards has relationship on employees performance

\begin{tabular}{llllll}
\hline Items & $\mathbf{O}$ & $\mathbf{E}$ & $\mathbf{O - E}$ & $(\mathbf{O}-\mathbf{E})^{2}$ & $(\mathbf{O - E})^{2} / \mathbf{E}$ \\
\hline $\begin{array}{l}\text { Strongly } \\
\text { Agree }\end{array}$ & 130 & 32.6 & 97.4 & 9486.8 & 291.00 \\
Agree & 23 & 32.6 & -9.6 & 92.16 & 2.83 \\
Undecided & 5 & 32.6 & -27.6 & 761.8 & 23.37 \\
Decided & 3 & 32.6 & -29.6 & 876.2 & 26.88 \\
$\begin{array}{l}\text { Strongly } \\
\text { Disagree }\end{array}$ & 2 & 32.6 & -30.6 & 936.4 & 28.72 \\
Total & 163 & 163 & 0 & 12153 & 372.8 \\
\hline
\end{tabular}

Note. Calculated value $=372.8$; Degree of freedom $=4$

Reward systems are outcomes or events in the organization that satisfy work related needs. ${ }^{[32]}$ Rewards include intrinsic and incentives types like promotions, re-assignment and non-monetary bonuses. Furthermore, high morale and productivity go hand in hand, it is however imperative on managers to reward employees when they hit organizational targets and stretched standards set by the organization. A properly administered system of reward has the capacity not only to implore incentives for quality workmanship and staff performance but also based on how skilled employees to join the organization.

Hypothesis 11, the result revealed on a positive relationship between non-monetary and employees productivity. The result is in conformity with the works of who postulated that non- monetary reward is focused on recognition, opportunity and career advancement. ${ }^{[16]}$

Non-monetary reward systems mostly benefit the culture of the organization and the bottom line. When rewards for performance are not based upon money, the culture of an organization tends to value recognition instead of the drive for money. It is revealed that non-monetary reward is public recognition for organization achievements. If an employee or workers performs exceptionally well at her job, an organization can gather its workers around the employees for a round of applause in her honors. The employee receives a boost of self-confidence for the gesture and recognizes that her contribution makes a difference. Additionally, an organization can write letters of gratitude to employees, offer refreshments and create an employee recognition wall. Organizations use reward systems as an incentive for employees to maximize their work productivity and quality. Non-monetary reward system emphasizes the importance of recognition among peers and workplace.

\subsection{Summary}

The research aimed at assessing effective reward system on employee's a case study of UCTH Reward systems are a vi- tal aspect of any organization since it serves as a motivating factor to improve upon employees' efficiency, effectiveness and loyalty to organizational goals and targets. It can either be extrinsic or intrinsic.

This study shall be of great importance to corporate entities within organizations since it will serve as an eye-opener to recognize employee's as an important facilitators in an organization. To further progress with the study, questionnaires designed which was comprehensive enough to address the various objectives of the researchers. From the analysis it was established that:

(1) Monetary rewards had a positive impact on employees performance

(2) Monetary rewards are tools of growth and development in an organization

(3) Monetary rewards had a significant relationship on organizational performance

(4) Non-monetary rewards leads to employees performance through recognition and opportunities

(5) Monetary and non-monetary rewards are instruments that catalyze the growth of an organization

(6) Accomplishing tasks and achieved targeted goals are achieved

(7) It was shown that methods used in implementing rewards are performance based methods and promotion based method

\section{Conclusion}

The study empirically examined on the effect of reward system on employee's performance. In any organization, employees reward companies of policies and in accordance with their skill Every organization (UCTH inclusive) needs a strategic reward system for employees. Monetary rewards are financial inducement that positively leads to high productivity in the organization.

Rewards systems are the planned activities that organizations implement to achieving the set goals of the organization. Managing human resources which is the most valued asset of an organization, has received much attention recently a lot could be gained from a better handling of human resource within organization. Most organizations view their systems of rewarding employees as an additional cost of doing business which should not be so because it is very salient to reward employees and the outcome is that it motivates them to put in more efforts, skills and ability which at the long run increases productivity. It is concluded that reward system is based on the assumption that rewarding employees would attract, retain and motivate workers. 


\section{REFERENCES}

[1] Kreitner R, Kinicki A. Organizational Behavior (6th ED). New York: McGraw-Hill Companies Inc; 2004.

[2] Oyira EJ. Concept of management and organization in nursing care services. Calabar: Unical Printing Press; 2010.

[3] Bratton J, Gold J. Human resources management: Theory and practice (4th ED). Basingstroke: Palgrave Macmillan; 2007.

[4] Dada GO. Motivation as a tool of management in the local government area. Abeokuta: Nigeria Consults; 2004

[5] Okoronkwo IL. Nursing science administration and management. Enugu: Enugu Campus; 2005.

[6] Ahmad S, Ali I, Rehman K, et al. Insecure job and low pay leads to job dissatisfaction. Interdisciplinary Journal of Contemporary Research in Business. 2010; 1(11)

[7] Schaufeli WB, Saianova M, Gonzales-Roma V, et al. The measurement of engagement and burnout: a two sample confirmatory factor analytic approach. Journal of Happiness Studies. 2002; 3(1): 71-92. http://dx.doi.org/10.1023/A:1015630930326

[8] Bartol KM, Srivastava A. Encouraging knowledge sharing: the role of reward systems. Journal of Leadership and Organization Studies. 2002; 9: 64-76. http://dx.doi.org/10.1177/1071791902009 00105

[9] Schuler RS, Jackson SE. Human resources management and its link with strategic management. In B. Gerhart \& J. Hollenheck (EDs). Human Resources Management. London: Thompson international; 2002. 66-72.

[10] Schutt R. Investigating the social world: The process and practice of research (5th ED). Thousand Oaks, CA; 2006.

[11] Shore LM, Shore TH. Perceived organizational support and organizational justice. In R. Cropanzano \& K. M. Kacmar (EDs), Organizational politics, justice, and support: Managing social climate at work. Westport, CT: Quorum Press; 1995. 149-164. PMid: 7544902.

[12] Paauwe J, Boselie P. Human resource management and performance: What next? Human Resource Management Journal. 2005; 1(6): 987 995.

[13] Dessler G. Human resource management (10th ED). New Delhi: Dorling Kindersley; 2006.

[14] Beauregard TA, Henry LC. Making the link between work-life balance practices and organization performance. Human Resource Management Review. 2009; 19(2): 19-22.

[15] O'Reilly CA III, Chatman J. Organizational commitment and psychological attachment: The effects of compliance, identification, and internalization on prosocial behaviour. Journal of Applied Psychology. 1986; 71: 492- 499. http://dx.doi.org/10.1037/0021-9 010.71 .3 .492

[16] Harmon P. Business process change (2nd ED): A guide for business managers and BPM and Six Sigma professionals. Business Process Trends, The MK/OMG Press; 2007.
[17] LaBelle JE. The paradox of safety hopes and rewards: Are you rewarding the right behaviour? Professional Safety. 2005; 37-39.

[18] Teddie C, Tashakkori A. Foundations of mixed methods research. Sage Publications, Thousand Oaks, CA; 2008. 173-174.

[19] Nelson B, Spitzer DR. The 1001 rewards \& recognition fieldbook: the complete guide (1st ED). New York: Workman Publishing Company; 2000 .

[20] Cho S, Woods RH, Jang S, et al. Measuring the impact of HRM Practices on hospitality firms' performance. Hospitality Management 2006; 25: 262-277. http://dx.doi.org/10.1016/j.ijhm.20 05.04 .001

[21] Wong OM, Dean AM, White CJ. Analyzing service quality in the hospitality industry. Managing Service Quality. 1999; 9: 136-143. http://dx.doi.org/10.1108/09604529910257920

[22] Peters LH, Jackofsky EF, Salter JR. Predicting turnover: a comparison of parttime and full-time employees. Journal of Occupational Behaviour. 1981; 2: 89-98. http://dx.doi.org/10.1002/job .4030020204

[23] Tax SS, Brown SW. Recovering and learning from service failure Sloan Management Review. 1998; 40: 75-88.

[24] Chen CC. New trends in reward allocation preferences: A Sino-US comparison. Academy of Management Journal. 1995; 38: 408-28. http://dx.doi.org/10.2307/256686

[25] Cosgrove D. Talent management human resources. New Zealand Magazine for HR Professionals. 2005; 10(1): 22-23.

[26] Chiang FFT, Birtch TA. Reward climate and its impact on service quality orientation and employee attitudes. International Journal of Hospitality Management. 2010.

[27] Johnson RE, Chang C, Yang L. Commitment and motivation at work: the relevance of employee identity and regulatory focus. Academy of Management Review. 2010; 35 (2): 226-245. http: //dx.doi.org/10.5465/AMR. 2010.48463332

[28] Creswell J. Research design: Qualitative and quantitative approaches London: Sage; 1994.

[29] Plessis AJ, Nel PS, Struthers L, et al. Does HRM add value to organizations in New Zealand or is it just another job? International Review of Business Research Papers. 2007; 3(3): 277-96.

[30] Singh S, Dixit PK. Employee involvement: An approach to organizational development and change. International Journal of Business and Finance Management Research. 2011; 1(8): 554-560.

[31] Kelinger FN. Foundations of behavioural research. New York: Holt, Phinehart and Winston; 1987.

[32] Kessler L, Purcell J. Performance related pay: objectives and applications. Human Resource Management Journal. 1992; 2 :16-33. http: //dx.doi.org/10.1111/j.1748-8583.1992.tb00258.x 